\title{
IDENTIFIKASI FAKTOR-FAKTOR PENGHAMBAT BELAJAR RENANG
}

\author{
Sandra Arhesa ${ }^{1}$, Davi Sofyan ${ }^{2}$ dan M. Faisal Ramadhan ${ }^{3}$ \\ Universitas Majalengka, Indonesia \\ e-mail: arhesasandra@unma.ac.id
}

\begin{abstract}
ABSTRAK. Penelitian ini bertujuan untuk mengetahui faktor-faktor penghambat dalam proses belajar renang. Metode penelitian yang digunakan yaitu penelitian deskriptif menggunakan metode survey. Subjek dalam penelitian ini adalah siswa SMK Al- Huda Kedungwungu, dengan populasi siswa sejumlah 1308 dan sampelnya 52 siswa. Teknik dalam pengambilan sampel menggunakan purposive sampling. Intrumen yang digunakan berupa angket. Analisis data menggunakan teknik deskriptif kuantitatif dengan menghitung persentase. Hasil Penelitian sebanyak 59.9\% siswa yang tidak tertarik belajar renang, faktor-faktor penghambat belajar renang terdiri dari sarana dan prasarana sebanyak $62.5 \%$, resiko belajar renang sebanyak $69.6 \%$, rasa cemas pada saat belajar renang sebanyak $64.7 \%$, rasa takut pada saat belajar renang sebanyak $73 \%$, dan pengaruh lingkungan sebanyak 45\%. Sehingga dari hasil tersebut diketahui bahwa faktor resiko, cemas, dan takut lebih menghambat dibandingkan dengan faktor belajar renang lainnya seperti sarana dan prasarana serta lingkungan.
\end{abstract}

Kata Kunci: Faktor Penghambat; Belajar Renang

\section{Pendahuluan}

Perkembangan olahraga di Indonesia mengalami peningkatan yang berarti. Kesadaran masyarakat bahwa olahraga sangat penting bagi kesehatan tubuh untuk menunjang aktivitas sehari-hari. Contohnya seperti di kolam renang banyak rombongan siswa-siswi sekolah dari tingkat SD sampai SMA/K dan rombongan ibu-ibu yang membawa anak-anaknya untuk berekreasi sekaligus berolahraga. Mereka belajar renang di bawah koordinasi guru atau pelatih. Sesuai dengan teori bahwa renang menurut Pratiwi (2015) adalah "salah satu cabang olahraga yang dapat diajarkan pada anak-anak dan orang dewasa, bahkan bayi yang berumur beberapa bulan saja sudah dapat mulai diajarkan renang" sedangkan Arhesa (2020) mengemukakan bahwa renang merupakan kegiatan yang banyak diminati oleh berbagai kalangan, mulai dari usia anak-anak sampai dewasa, bahkan sampai usia lanjut. Karena selain menyenangkan berguna untuk kesehatan juga.

Pembelajaran renang merupakan kegiatan yang sangat menyenangkan, ini ditunjukan semakin banyaknya para peserta didik secara rutin melakukan olahraga renang walaupun kenyataanya belum bisa berenang. Tetapi ketika sudah berada di dalam kolam renang mereka berusaha untuk bisa berenang, walaupun gerakan mereka tidak sesuai dengan gaya yang sudah ada atau sesuai aturan contohnya seperti gerakan tangan menggunakan gaya dada dan gerakan kaki menggunakan gaya bebas. Sehingga sebagian dari mereka menghabiskan waktunya di 
kolam renang. Disamping itu belajar renang dapat membantu masa pertumbuhan, perkembangan anak, dan meningkatkan kebugaran jasmani.sedangkan menurut Soekarno (Arhesa, 2020) bahwa olahraga renang sangat berguna sebagai alat pendidikan, rekreasi yang sehat, menambah keberanian, percaya diri dan terapi yang kadang-kadang dianjurkan oleh dokter.

Pendidikan memiliki sasaran pedagogis, oleh karena itu pendidikan kurang lengkap tanpa adanya pendidikn jasmani, olahraga dan kesehatan, karena gerak sebagai aktivitas jasmani adalah dasar bagi manusia untuk mengenal dunia dan dirinya sendiri secara alami berkembang seiring dengan perkembangan zaman. Pendidikan jasmani olahraga dan kesehatan merupakan media untuk mendorong pertumbuhan dan perkembangan fisik maupun mental, pengetahuan dan penalaran, serta sportifitas dalam mencapai suatu hal. Serta pembiasaan pola hidup sehat yang merangsang perkembangan dan pertumbuhan fisik ataupun mental yang seimbang. Selama ini telah terjadi kecenderungan dalam memberikan makna mutu pendidikan yang hanya dikaitkan dengan kemampuan kognitif. Pandangan ini telah membawa akibat terabaikannya aspek-aspek moral, akhlak, budi pekerti, seni, psikomotor, serta lifeskill. Oleh karena itu lembaga pendidikan akan memberikan kebijakan peluang untuk menyempurnakan kurikulum yang komperhensif dalam rangka mencapai tujuan pendidikan nasional. Menurut Andriani dan Ladjar (2018) "Pendidikan disekolah memiliki peran untuk memiliki peran untuk menumbuhkan dan mengembangkan kemampuan berpikir kreatif dari usia dini dan remaja". Salah satunya yaitu dengan mempelajari olahraga renang.

Materi renang sangat tepat diberikan pada masa-masa sekolah untuk tujuan tersebut. Sebab masa-masa sekolah umur anak dalam masa pertumbuhan atau perkembangan baik fisik maupun mental. Menurut Anggara (2018) "Pendidikan jasmani merupakan bagian yang tidak terpisahkan dari pendidikan nasional yang bertujuan untuk kemampuan peserta didik melalui aktivitas jasmani”. Pada kenyataanya tidak semua sekolah mampu memasukan materi renang ke dalam mata pelajaran pendidikan jasmaninya. Hal ini karena beberapa faktor seperti sarana dan prasarana yang ada di sekolah tidak memungkinkan untuk belajar renang atau kolam renang jauh dari sekolah. Untuk itu diharapkan dukungan dari pemerintah agar sekolah dan pihak-pihak terkait untuk membangun kolam renang dan fasilitas olahraga lainnya agar para peserta didik dapat menerima materi khususnya renang di sekolahnya masing-masing tanpa harus keluar dari lingkungan sekolah. Sekarang ini pembelajaran renang masuk dalam pembelajaran pendidikan jasmani di sekolah guna memperdalam dan mengekplorasi pengetahuan peserta didik terhadap pembelajaran renang, menyalurkan bakat, dan minat melengkapi upaya pembinaan manusia seutuhnya. Selain itu guru juga harus mengerti keadaan 
siswa, sehingga dapat menerapkan pengelolaan kelas dengan tepat mengenai materi yang diajarkan dalam proses pembelajaran.

Proses belajar sering kali mengalami berbagai masalah atau hambatan sehingga mengganggu proses belajar mengajar itu sendiri. Pembelajaran renang yang masuk dalam materi pendidikan jasmani biasanya menghadapi masalah antara lain: 1) peserta didik menghawatirkan atau cemas keselamatannya saat berada didalam kolam renang, 2) beberapa peserta didik merasa takut atau mengalami pengalaman buruk pada masa lalunya, 3) kondisi internal dan eksternal atau lingkungan para peserta didik.

Berdasarkan yang akan dilakukan di suatu lembaga pendidikan tidak semua peserta didik bisa mengikuti pembelajaran renang karena faktor-faktor penghambat. Namun sejauh ini belum diketahui hal-hal yang menghambat peserta didik tersebut untuk ikut masuk ke dalam proses belajar renang. Hal ini yang mendorong peniliti untuk menemukan hambatan pada proses belajar renang di SMK Al-Huda Kedungwungu Anjatan Indramayu. Dari hasil uraian diatas dan dari hasil pengamatan yang dilakukan, maka peneliti bermaksud melakukan penelitian tentang "Identifikasi Faktor-faktor Penghambat Belajar Renang".

\section{Metode Penelitian}

Metode penelitian yang penulis gunakan dalam penelitian ini adalah deskriptif kuantitatif dengan metode survei, Subjek dalam penelitian ini adalah siswa SMK Al-Huda Kedungwungu. Populasi siswa SMK Al-Huda Kedungwungu berjumlah 1308 orang. Teknik pengambilan sampel dari penelitian ini adalah purposive sampling. Alasan mengambil purposive sampling karena dari sekian banyak populasi, sampel yang dibutuhkan hanya peserta didik yang telah teridentifikasi. Maka sampel penelitian yang di gunakan sebanyak 52 siswa. Untuk memperoleh data yang sesuai dengan yang diharapkan penulis menggunakan angket sebagai instrumen penelitian. Instrumen diuji menggunakan korelasi product moment, dan diperoleh validitas total 0,725. Uji reliabilitas instrumen menggunakan rumus Alpha Cronbach, dan diperoleh koefisien reliabilitas sebesar 0,919. Sedangkan teknik analisis data digunakan teknik deskriptif kuantitatif dengan menghitung presentase.

\section{Hasil dan Pembahasan}

Dari nilai keseluruhan semua sampel angket yang dibagikan ke 52 siswa menunjukan bahwa hasil sebanyak 59.9\% siswa yang tidak tertarik belajar renang. Ternyata penyebabnya ada beberapa faktor-faktor penghambat dari belajar renang diantaranya dari sarana dan prasarana sebanyak $62.5 \%$, resiko belajar renang sebanyak $69.6 \%$, rasa cemas pada saat belajar renang 
sebanyak $64.7 \%$, rasa takut pada data belajar renang sebanyak $73 \%$, dan pengaruh lingkungan sebanyak $45 \%$.

\section{Pembahasan}

\section{Faktor-faktor Penghambat Belajar Renang}

a. Sarana Prasarana

Berdasarkan hasil menunjukan bahwa faktor sarana dan prasarana menjadi penyebab faktor penghambat belajar renang sebanyak (62.5\%). Dari faktor itu terbanyak dipengaruhi oleh tidak lengkapnya fasilitas kolam dan kurangnya rasa nyaman peserta didik ketika kolam ramai pengunjung. Aspek menejerial fasilitas dalam proses belajarmengajar dalam pendidikan jasmani ialah distribusi perlengkapan sebelum proses belajar-mengajar dan pengumpulan perlengkapan sesudah proses tersebut. Seperti halnya fasilitas pendidikan jasmani yang ada di dalam ruangan atau di luar ruangan, fasilitas kolam renang harus memenuhi prasyarat keselamatan.

b. Resiko

Faktor resiko menjadi penyebab faktor penghambat belajar renang sebanyak (69.6\%), dari faktor itu terbanyak di pengaruhi oleh karena human eror atau kurang berhatihatinya para peserta didik. Oleh karena itu peneliti memberikan rekomendasi untuk memperkecil resiko yang akan ditimbulkan. Seperti mengedukasi para peserta didik untuk mengikuti proses pembelajaran renang, karena itu bisa memperkecil peserta didik terjatuh dari pinggir kolam yang licin karena basah, maupun pedihnya mata pada saat berenang.

c. Cemas

Faktor cemas juga menjadi penyebab faktor penghambat belajar renang yaitu sebanyak (64.7\%), karena faktor itu terbanyak di pengaruhi oleh rasa cemas ketika diperhatikan oleh guru dan teman-teman sekelasnya, serta ketika melihat kolam yang dalam. Sehingga rasa cemas yang ditimbulkan pada saat berenang bervariasi. Oleh karena itu peneliti merekomendasikan guru harus mampu memberikan dukungan agar siswa/i bisa lebih percaya diri,dan salah satunya dengan belajar di kolam yang dangkal untuk melawan rasa cemas yang ditimbulkan pada saat pembelajaran renang berlangsung.

d. Takut

Faktor takut menjadi penyebab faktor penghambat belajar renang sebanyak $(73 \%)$. Faktor tersebut terbanyak di pengaruhi ketika para peserta didik melihat kolam yang dalam dan kurang siapnya peserta didik dalam mengikuti materi baru, karena itu 
peneliti merekomendasikan kolam yang dangkal, membuat permainan yang kreatif sehingga siswa lupa dengan rasa takut yang mereka alami pada saat pembelajaran renang berlangsung, dan memberikan materi yang jelas dan tersusun rapih sehingga dapat dimengerti oleh para peserta didik dikala memasuki materi yang baru.

\section{e. Lingkungan}

Berdasarkan hasil perhitungan menunjukan bahwa lingkungan tidak terlalu dominan untuk menghambat belajar renang karena hanya sebanyak (45\%). Hasil tersebut tidak boleh dianggap remeh karena jika faktor lingkungan yang tidak mendukung belajar peserta didik akan mempengaruhi hasil belajar tersebut. Lingkungan merupakan bagian dari peserta didik yang berpengaruh terhadap perkembangan anak. Kondisi lingkungan merupakan unsur-unsur yang datang dari luar diri siswa. Lingkungan siswa, sebagaimana juga lingkungan individu pada umumnya ada tiga, yaitu lingkungan keluarga, sekolah, dan masyarakat. Keluarga yang tidak utuh baik secara struktural maupun fungsional, kurang memberikan motivasi terhadap perkembangan belajar siswa. Ketidakutuhan dalam keluarga akan menimbulkan kurangseimbangan baik dalam pelaksanaan tugas-tugas keluarga maupun dalam memikul beban keluarga. Menurut Pamungkas (2012) dalam penelitian nya menyatakan bahwa faktor lingkungan termasuk dalam salah satu terjadinya penghambat dalam proses belajar renang.

\section{Belajar Renang}

Berdasarkan hasil perhitungan menunjukan yang tidak tertarik belajar renang sebanyak (59.9\%). Dari faktor tersebut terbanyak dipengaruhi oleh para peserta didik menganggap renang sebagai ajang rekreasi bukan untuk belajar. Oleh karena itu peneliti merekomendasikan mengedukasi peserta didik agar lebih serius untuk mengikuti pembelajaran renang.

Belajar renang merupakan salah satu materi yang ada di mata pelajaran pendidikan jasmani. Untuk mencapai tujuan belajar dalam pendidikan jasmani siswa-siswi harus mengikuti pembelajaran renang demi mencapai tujuan belajar tersebut. Dalam penelitian ini peneliti mengemukakan bahwa para peserta didik sebagian besar tidak berminat dalam mengikuti pembelajaran renang. Faktor- faktor yang menghambat dalam kegiatan tersebut adalah sarana dan prasarana, resiko yang akan ditimbulkan, rasa cemas dalam masa pembelajaran renang itu berlangsung, rasa takut, dan faktor lingkungan.

Oleh karena itu peneliti merekomendasikan beberapa saran untuk para pengajar agar siswa-siswi tertarik dalam mengkuti pembelajaran renang, yaitu: 1) Menyediakan sarana dan prasaran yang memadai dan layak sehingga peserta didik nyaman mengikuti 
pada saat pembelajaran berlangsung, 2) Memberikan pengetahuan dasar dalam berenang seperti harus pemanasan agar tidak gampang mengalami kram saat pembelajaran berlangsung, 3) Mencari kolam yang dangkal sehingga peserta didik tidak merasakan cemas dan takut. Atau perasaan yang aneh ketika pembelajaran renang berlangsung, 4) Mengedukasi peserta didik agar tidak mudah terpengaruh arus lingkungan yang tidak baik.

\section{Kesimpulan}

Faktor-faktor penghambat belajar renang terdiri dari sarana dan prasarana sebanyak $62.5 \%$, resiko belajar renang sebanyak 69.6\%, rasa cemas pada saat belajar renang sebanyak $64.7 \%$, rasa takut pada data belajar renang sebanyak 73\%, dan pengaruh lingkungan sebanyak $45 \%$. Dari hasil tersebut diketahui bahwa faktor resiko, cemas, dan takut lebih menghambat dibandingkan dengan faktor lainnya seperti sarana dan prasarana serta lingkungan.

\section{Daftar Pustaka}

Andriani, M. dan Ladjar, B. (2018). Pengaruh Model Problem-Based Learning dan Discovery Learning serta Kecerdasan Intelektual terhadap Berpikir Kreatif. Jurnal Pendidikan Jasmani dan Olahraga, 22-33.

Anggara, S. T. (2018). Revitalisasi Pendidikan Jasmani untuk Anak Usia Dini melalui Penerapan Model Bermain Edukatif Berbasis Alam. Jurnal Pendidikan Jasmani dan Olahraga, 41-51.

Arhesa, S. (2020). Buku Jago Renang untuk Pemula Nasional dan Internasional. Tangerang: Cemerlang.

Pamungkas, S. H. (2012). Identifikasi Faktor-faktor Penghambat Belajar renang pada Siswa Kelas XI di SMKN 1 Depok. (Skripsi). Pendidikan Jasmani dan Rekreasi. Yogyakarta: FIK UNY

Pratiwi, I. (2015). Sekolah Renang di Kota Semarang Dengan Penekanan Design Sustainable Architecture. Jurnal Unnes, 1-9.

Soekarno. (1984). Olahraga untuk Perguruan Tinggi. Yogyakarta: IKIP 